\title{
Populism and the people in Lula's political discourse: Bridging linguistic and social theory
}

\section{Populismo e o povo no discurso político de Lula: Uma ponte entre teoria linguística e social}

Bruno Coutinho

IESP/UERJ

brunocouti@gmail.com

Adriana Carvalho Lopes

UFRJ

adrianaclopes14@gmail.com

Daniel do Nascimento e Silva

UFRJ

dnsfortal@gmail.com

\begin{abstract}
This paper combines conceptual tools from discourse and social theories to analyze a particular speech that former Brazilian president Luiz Inacio Lula da Silva delivered at the end of his second term (2007-2010) in the Complexo do Alemão, a neighborhood located in one of the poorest areas of Rio de Janeiro. It attempts to highlight how Lula breaks with a longstanding tradition of Brazilian politicians who have chiefly represented the political elites. While using a specific rhetoric, Lula constructs (and is constituted by) a "populist" locus of enunciation. Drawing from Ernesto Laclau's theory of populism, this paper argues that populist logic in Latin America should not be understood pejoratively, but rather as a particular way of doing politics. It thus claims that Lula positioned himself and his interlocutors as "the people," a specific
\end{abstract}


discourse that breaks with certain Eurocentric expectations about the "appropriate" language of politics in Brazil.

Keywords: Discourse; text; context; Lula; Complexo do Alemão; populism.

Resumo: Este artigo articula conceitos oriundos tanto da teoria linguística quanto social de forma a analisar um discurso proferido pelo expresidente do Brasil, Luiz Inácio Lula da Silva, no fim do seu segundo mandato (2007-2010) no Complexo do Alemão, um bairro localizado em uma das regiões mais pobres do Rio de Janeiro. O artigo aborda o modo como Lula rompe com uma tradição de políticos brasileiros que representam primariamente as elites. Por meio de uma retórica específica, Lula constitui (e é constituído por) um lugar de enunciação "populista". Engajado com a teoria do populismo de Ernesto Laclau, este artigo propõe que o populismo na América Latina seja entendido não de modo pejorativo, mas como um modo próprio de realizar política. Assim, argumenta-se aqui que Lula posicionou a si e a seus interlocutores como "o povo", um discurso específico que rompe com certas expectativas eurocêntricas do que seja a linguagem "apropriada" da política no Brasil.

Palavras-chave: Discurso; texto; contexto; Lula; Complexo do Alemão; populismo.

Recebido em: 25 de janeiro de 2016.

Aprovado em: 05 de agosto de 2016.

To begin with, it's a contradiction that someone's child studies in a school with air-conditioning while another's child cannot even write because the room is so hot that the sweat drips down into the notebook.

(LULA, 2010, p. 4)

\section{Introduction}

A former migrant from the poor Nordeste (Northeast) of Brazil and later a union leader in the wealthy state of São Paulo and one of the founders of the Workers Party (henceforth, the PT), Luiz Inácio Lula da 
Silva served as president of Brazil in two consecutive terms between 2003 and 2010. During his presidency, Lula (as he is commonly referred to in Brazil) was frequently in the news not only for what he did, but also for what he said and how he said it. His speech was frequently treated by the corporate media and by some Brazilian intellectuals as a form of "deviation," "error," "expression of ignorance", or as an "abnormal style" in need of being corrected. His grammar was often regarded as flawed, his metaphors were considered laughable, his working class speech register was scorned, and above all the "content" of his speech was frowned upon. Much of this negativity and discontent stems from the fact that Lula often broke with commonly held expectations about the adequate political language in Brazil (DALTOÉ, 2010 and SIGNORINI, 2006, 2014). Yet Lula has had an internationally recognized career as the president who lifted millions out of poverty and put Brazil on the path to development.

While situating ourselves in an interdisciplinary combination of linguistic and social analysis, we address in this paper some challenges that Lula's discourse posed to the traditional language of politics in Brazil. All in all, Lula departed from a longstanding tradition of Brazilian politicians who had chiefly represented the political elites. We argue that Lula, in using a specific rhetoric, constructed (and was constituted by) a "populist" locus of enunciation.

Drawing on Ernesto Laclau's theory of populism, we claim that populist logic in Latin America should not be understood pejoratively, but rather as a particular way of doing politics. Unlike classical theories of populism (IANNI, 1989; 1994; WEFFORT, 2003), which conceive it in a pejorative way, or as a deviation from the natural evolution of Brazilian society, Laclau claims that populism is the very essence of the political scene.

In order to present an account of Lula's populist locus of enunciation, we methodologically attempt to bridge pioneering analytical instruments of discourse analysis (FAIRCLOUGH, 1993; van DIJK, 2008; LACLAU, 2005; WODAK, 2011) with an interpretative disposition that Signorini (2002, p. 122) has termed "contextual ethnographic analysis" or "ethnographic perspective" (see also PINTO, 2015; GARCEZ; SCHULZ, 2015). We thus attempt to provide a token of Signorini's contextual ethnographic analysis, and we do so in order 
to provide scholarship on language that does not detach itself from a careful consideration of society.

Along these lines, we analyze a particular speech that Lula delivered at the end of his second term as president (2007-2010) in the Complexo do Alemão, a neighborhood located in one of the poorest areas of Rio de Janeiro. Author Bruno was present at this event and had the chance to accompany first-hand a great deal of the process of production of Lula's speech. While working on his Masters thesis, aimed at studying the impacts of the Program of Acceleration of Growth in the Complexo do Alemão (OLIVEIRA, 2011), the author spoke with Lula's press advisors and some displaced families that Lula's staff had interviewed in order to situate the president's speech within local "real life" stories.

Our analysis of Lula's speech will be also based on a interview with Gloria, a journalist who had worked during his incumbency as staff member of the Presidency Secretariat for Social Communication (henceforth, SECOM). Composed of journalists, intellectuals and some leaders in the government, the Secretariat was responsible for the conception and production of the print version of Lula's speech (an artifact that Lula would transform in his public oral performances), and for the transcript of the oral text that would be made available in the Presidency website. In our contextual ethnographic analysis, studying Lula's speech vis-à-vis Gloria's remarks and other accompanying discourses is a mode of accounting for the complexity of given utterances - discursive artifacts that, as Bakhtin (1986) reminded us, stand as links in a succession of other utterances.

This article is organized as follows: We first present our read of the notion of locus of enunciation and spell out our conception of discourse. Then we describe the collective construction of the speech that Lula delivered in the Complexo do Alemão in 2010, at the inauguration of a housing complex for the poor. Next, we focus on the first part of Lula's speech and explore some linguistic features of his populist locus of enunciation. The analysis then turns to some metaphors that Lula uttered to position himself as a politician who is close to his allies and to God, while being wary of the dangers of political flamboyance. Next, we explore the concept of populist logic by Laclau (2005) and try to relate it to both Lula's performance in speech and his political agenda. Finally, we conclude that Lula explored features of discourse in ways that simultaneously respected and subverted the system of interdictions 
constraining his affordances in speech, thus producing a locus of enunciation that had been foreign to Brazilian national politics.

\section{Locus of enunciation and discourse}

We intend to analyze Lula's discourse by seeking to understand how social and linguistic factors constitute the locus of enunciation of a subject. As Mignolo (1994) aptly points, the loci of one's enunciation aren't a set of fixed linguistic sites but rather trajectories that subjects follow amidst a myriad ambivalent struggles, interdictions, and desires.

A few words on our conception of discourse are also necessary.

First, we here build on several authors who, despite their different disciplinary leanings, defend that discourses are ideological (FAIRCLOUGH, 1993; FOUCAULT, 1981; BAKHTIN, 1986; BLOMMAERT, 2005). By ideology we mean neither 'false consciousness' nor 'affiliation with hegemonic discourses.' We conceive of ideology instead in a more mundane and practical (BOURDIEU, 1977) sense, in which ideology is "some kind of 'social cement' [that] turns groups of people into communities, societies, and cultures" (BLOMMAERT, 2006, p. 510).

Second, we hold that subjects who utter discourses are not autonomous entities in a social vacuum, but rather actors who are constituted by (and authors of) discursive processes. The subject's utterance is always the re-uttering of some previously constituted linguistic unit in a language, and so the action of the subject in language is necessarily historical and ideological.

Third, we see discourse not as a mere linguistic or representational practice, but rather as a performative (AUSTIN, 1962) and material one, that is both social and historical and produces social reality. Fairclough (1993) emphasizes that discourse is a practice not just of representing, but also of giving meaning to the world, thereby constituting perspectives of action in society. In this framework, in order to understand social reality and identities one must first understand how and why such constructs are discursively produced. Along similar lines, Laclau (2005) argues that discourse is a material category, not precisely a mental or ideal fact. In short, discourse is a social practice inasmuch as any actions undertaken by subjects and social groups are meaningful actions. 
Fourth, all discourses are fundamentally heterogeneous. We will refer to discourses as practices that carry other accompanying voices and ideologies. As Bakhtin taught us long ago, every discourse is full of fragments of other discourses - linguistic units that may be explicitly demarcated or mixed with other utterances. A stretch of discourse may assimilate, contradict, deny or echo other discourses. Here, it is worth approximating the notion of discourse to that of 'utterance' in Bakhtin (1986). For the Russian Philosopher, "any utterance is a link in a very complexly organized chain of other utterances" (BAKHTIN, 1986, p. 69). Every utterance is thus constituted by an intense polyphony:

(...) the unique speech experience of each individual is shaped and developed in continuous and constant interaction with others' individual utterances. This experience can be characterized to some degree as the process of assimilation - more or less creative - of others' words (...). Our speech, that is, all our utterances (including creative works), is filled with others' words, varying degrees of otherness or varying degrees of "our-own-ness," varying degrees of awareness and detachment. These words of others carry with them their own expression, their own evaluative tone, which we assimilate, rework, and re-accentuate. (BAKHTIN, 1986, p. 89)

Building upon these established principles of discourse, we here analyze the speech of Lula as he produces his own locus of enunciation in a public gathering at a group of poor neighborhoods of Rio de Janeiro - a locus of enunciation that is, as a condition of its own possibility, already plural and polyphonic. Also, to the extent that the subject who utters "I" in language is necessarily positioning him/herself in relation to a "you" (BENVENISTE, 1973), we will take into account how Lula discursively represents his interlocutors.

We believe that this perspective is fundamental in our critique of the discourses of Lula as he assumes the position of a "public man" in the ways he addresses his interlocutors. As Foucault argued, the authorial position of a subject is different from a metaphysical notion of authorship. That is, there is no primary origin of discourses and meanings. Authorship is rather "an empty function that can be filled by virtually any individual when he formulates the statement" (FOUCAULT, 1972, p. 93). 
While focusing on the loci of Lula's enunciation in a specific speech event, we're also focusing on the space-time of his discourse, identifying privileged interlocutors, and exploring how he refers to both public policies and the role of the State. Besides, we will interpret how Lula produces the "people" (theoretically, the target of politics). Note that the category of the "people" is not an "ontology" that exists independently of discourse, nor is it "a static category that can be measured in economic and/or sociological terms" (MENDONÇA; LOPES, 2013). It is rather a discursive construction that can be signified in different ways with regard to the power relations in which it is inserted.

Having specified our read of both the notions of locus of enunciation and discourse, we'll turn in the next section to some ritualistic features of Lula's speech production. As Foucault taught us, the ritual is a complex system of restrictions that constitutes discourses (FOUCAULT, 1981). As we hope to demonstrate, Lula embedded his populist locus of enunciation not only in the myriad conflicting demands of institutional politics but also within a specific ritual.

\section{The Ritual of Preparing Lula's Speech}

\subsection{Broader Context: Favelas}

Former President Lula da Silva's speech took place at the inauguration of a housing complex in the Complexo do Alemão, one of the poorest neighborhoods of the city of Rio de Janeiro. The Complexo do Alemão is a group of 12 slums (known as "favelas") in Northern Rio de Janeiro where some 120,000 people live.

Favelas or irregular urban agglomerations have long been called 'shantytowns' in English (ZALUAR, 2010). However, the term is no longer appropriate as Rio de Janeiro's favelas are not comprised of shacks but rather houses built by residents with bricks and concrete. The official 2010 census estimates that some 1,393,300 people live in the 763 favelas spread throughout Rio de Janeiro. Rio has a population of approximately 6,323,000; therefore $22 \%$ of them live in irregular dwellings (IBGE, 2010).

Favelas are ethnically heterogeneous, including low-income descendants of Africans, Europeans and indigenous Brazilians. Rio the second largest city in Brazil - has the largest population of favela 
residents. These neighborhoods have the lowest rates of employment, education and public services. The Complexo do Alemão, for instance, has the lowest Human Development Index (0.38) in the 30 administrative regions of Rio de Janeiro. One third of its inhabitants are unemployed; out of the $40.8 \%$ who self-identified as employed in the 2010 national census, most hold positions for which educational requirements are low, working conditions are bad, and wages are worse (IBGE, 2010).

We should add that favelas are at once a byproduct of long-lasting inefficient urban planning and an icon of human agency. Yet hegemonic discourses usually position favelas in space-times that ignore their complex processes and logics of formation while invoking topographies and temporalities of human evil, crime and (intentional) segregation from the city. Slogans like the "fractured city" (VENTURA, 1995) or "neighborhoods that lack culture and peace" rapidly got combined under an "authoritarian political culture" (NOBRE, 2013, p. 30) inherited from Brazil's military dictatorship of over two decades (1964-1985), opening up a symbolic terrain where a police State should "bring" things: culture, public services, peace.

\subsection{Immediate Context}

Lula uttered his speech to an audience comprised of favela residents, local community leaders, and some political and institutional authorities (namely, the governor and vice-governor of the state of Rio de Janeiro, the city mayor, State ministers, senators, federal congress representatives, city representatives, the president of Caixa Econômica Federal, and State and city secretaries). The speech took place on October 25,2010 , seven months after heavy rains had provoked mudslides in the neighborhood, leaving some 400 families homeless. The houses were built with resources from the federal housing program known as "Minha Casa Minha Vida" [My home, my life] that helps the poor to acquire affordable apartments by offering loans from Caixa Econômica Federal, a public bank. As many families had been displaced due to the mudslides, local community leaders had demanded that the homeless be prioritized over those who had previously signed up for the loans but already had a place to live.

The April 2010 heavy rains displaced many families in the Complexo do Alemão and other areas of the city, causing a series 
of changes in the implementation of public policies in this group of favelas - relocation of finance resources, readjustment of schedules and methodologies, and the establishment of new local partnerships. The government of Rio de Janeiro would eventually announce that the 592 apartments built within the Minha Casa, Minha Vida program would be purchased by the State and destined to homeless families.

The inauguration of the housing complex also had electoral implications. At the time, politicians were campaigning for the Presidency, the Senate, the Congress and the State Government. Sergio Cabral, thengovernor of Rio de Janeiro, was campaigning to be re-elected, while Lula was supporting the campaign of his successor to the presidency, Dilma Rousseff. Therefore, the April 2010 floods, the "pressure" from homeless residents and the 2010 federal and state campaigns all comprise the immediate political context of Lula's speech.

\subsection{Lula's speech}

Our corpus consists of the transcript of Lula's speech and an interview with Gloria, ${ }^{1}$ a member of the SECOM, who provided us with a perspective on the process of production and dissemination of Lula's speeches.

In order not to read the loci of enunciation out of a bounded text, we'll reinforce our earlier point that an ethnographic perspective is essential in reading texts and their contexts. Here, we embrace an empirical perspective through our narration of Lula's ingenious production of his locus of enunciation. Thus our analysis of Lula's transcribed "text" is accompanied by a careful empirical consideration of other accompanying texts and practices.

The transcribed text has many marks of Lula's typical oral discourse. However, it isn't a facsimile copy of the "original" oral discourse, as we'll be using the transcription that Lula's press advisors made themselves. So this transcription is an entextualization (BAUMAN; BRIGGS, 1990) of his "original" discourse, i.e. it is a textual form whose units have traveled from another place, simultaneously carrying with themselves histories of their past context(s) and provoking disruptions in these histories. As such, this entextualized form is a phase of the process

\footnotetext{
${ }^{1}$ We are here using a pseudonym.
} 
of mediation of Lula's speech, or yet a translation, with all the linguistic and political connotations of the term.

To say that Lula's speech (like any speech) is mediated implicates at least two things. First, however original, singular and innovative Lula's rhetoric is, an artifact like the transcription we analyze here is not the very expression of Lula's "inner voice," but rather a set of entextualizations which are already polyphonic and iterable, a provisional place where, as Mignolo (1994, p. 508) aptly points, "conflictive enunciations remain to be deciphered behind or beyond the enunciated." Second, Lula's speech follows a ritual, a system of restrictions that impose limits, yet one whose possible breaches Lula knew (and exploited) very well. The following subsection is dedicated to explaining how Lula draws on both the history of entextualizations of Brazilian politics and on certain "breaches" of the (presidential) system of interdictions in order to enact the identity of a president who speaks like (and to) the People.

\subsection{The ritual}

Like any discourse, the President's discourse follows a specific ritual. Discourses are delimited by a set of constituting norms and rules, which at once provide the conditions for the individual's utterances and constrain his/her liberty in the process of formulating the discourse (FOUCAULT, 1981). In this sense, presidential discourses are ritualistic texts that enable certain choices within a field of restrictions.

Foucault highlights the "complex system of restrictions" that constitutes discourses. This system is the set of norms and rules that restrict the freedom of an individual in the process of discourse production. No one simply says what he or she pleases. Depending on the interlocutors, the individual makes moral and social choices that are determined by the "ritual" itself.

As there is no such thing as a toolkit that explains all features and specificities of the ritual framing of Lula's speech, Bruno's experience in the field was invaluable as it provided some evidence that explains how Lula's press advisors and the President himself handled some ritualistic injunctions. According to information from the Secretariat of the Presidency that Bruno gathered in the field, Lula's speech was planned as follows: in addition to protocol information (greetings and acknowledgements to authorities) that is required in the beginning of 
any presidential address, the speech would refer to "life stories" that the President's advisors had collected in their previous visit to the neighborhood. The stories would display the precariousness of life in the neighborhood, which would reinforce Lula's account of the benefits of his government's popular housing policy. Following these lines, two press advisors wrote the text that would later be read aloud by the President in public. But as it became clear at the event, Lula treated the print text as a mnemonic outline, one that he would combine with information gathered by him minutes before his public pronouncement, thus transforming the print guidelines into an oral performance that was not typical of Brazilian political language.

It is worth stressing here Gloria's input on the way Lula translated the print discourse that his press advisory would hand him (often) a day before his public speeches. Here she emphasizes that Lula would at once praise and subvert the written discourses previously elaborated by his Secretariat:

In general, he received [the written rendition of his speech] the day before or on the plane (...). He would often say that the discourse was too elaborated, that it had too many numbers and such, (...) but actually the text helped him prepare his own improved speech, with his own words. He would extract life stories and numbers from the text. I saw him many times reading the text on the airplane, that is, hours before the event. It was a transversal reading. Then he would place the pages vertically and organize them, and sometimes leave them on the plane seat or on his table. I sometimes saw him reading the text in the car or, in case he had slept in the city, while having breakfast. He would often bring the print version of the speech to the stage or the pulpit. But he rarely read it out to the public. I think I've never seen him reading it aloud. Only some stretches of it, or a specific number. He usually referenced the written texts in his own impromptu speech, cheerfully saying things like "don't worry, I won't read you this stack of papers. My press advisory made up this brochure to keep you here for two hours, but I won't bother you for so long." And the audience would respond with great fervor. He always started his speech by saying he wouldn't read the material, isn't that interesting? 
Note that even though his speech took place within an official "literacy regime" (BLOMMAERT, 2007), Lula engaged with the official literacy by twisting it altogether. Lula didn't simply read out or repeat the written text; he would instead re-iterate it as a novel text. As Gloria points out, his reiteration was ironic in that typical artifacts of the "pedagogic or institutional" literacy (STREET, 2009) such as institutional "stacks of paper" would be rendered as tedious objects that played only a secondary or supportive role. In these events, the authentic protagonist was his charismatic and populist oral rendition of the print artifacts.

The people's understanding of his discourse was not only his main concern, but also the guiding principle of his public readings. That is why for Gloria the formality of "too many numbers and such" wasn't the location of his transgressive performance. Lula seems to place his locus of enunciation on a singular terrain, or yet in the blindspot of the already established field of official politics. Performatively constituted in such terms, this emerging space would allow Lula to both attach himself and translate his politics to the public. This inventive translation process would ultimately produce affect in his audiences: "the audience would respond with great fervor. He always started his speech by saying he wouldn't read the material, isn't that interesting?", Gloria noted.

Lula's populist locus of enunciation was thus an ambivalent incorporation of institutional politics. In refusing to read out to the public a textual artifact produced by intellectuals (while at the same time drawing from it), Lula both reaffirmed and twisted Brazilian institutional politics. He rendered the convoluted discourse of the intelectual elites into a populist (textual) form, thereby reaching - hence, inventing - the "people".

In the Complexo do Alemão, Lula didn’t perform his populism any differently. Before stepping on the stage, the President personally talked to some of the beneficiaries of the federal housing program who would receive apartment keys on stage. This was a low-income context: Lula was in a favela, near the working classes he had been historically committed to. While listening to the residents, Lula became "intimate" with them. During his personal interactions with the residents, he would capture their framing of issues - personal fragments that Lula would translate into the larger scale of the Brazilian working class experience. This was one of the strategies that Lula devised and that helped him legitimize public policies for the poor.

Let us now switch to Lula's performance on stage, a place where he would further produce his locus of enunciation. 


\section{A populist locus of enunciation}

According to the protocol, Lula began his speech by greeting everyone who was present in the event:

(...) Bem, meus queridos companheiros e companheiras do Rio de Janeiro, meus queridos companheiros e companheiras do Complexo do Alemão, meu querido companheiro Sérgio Cabral, governador do estado do Rio de Janeiro e sua querida companheira Adriana Ancelmo Cabral, minha querida companheira Marisa, meus companheiros ministros Marcio Fortes, das Cidades; Dulci, da SecretariaGeral da Presidência; Franklin Martins, da Comunicação Social e o nosso companheiro Eloi Ferreira de Araujo, Ministro da Igualdade Racial. Quero cumprimentar o nosso querido companheiro Luiz Fernando Pezão, vice-governador e braço direito e esquerdo do companheiro Sergio Cabral, quero cumprimentar o nosso querido companheiro senador reeleito, Marcelo Crivella, quero cumprimentar a Deputada Federal Cida Diogo e deputado Jorge Bittar. Feliz aniversário, Jorge Bittar. Você, para quem aparenta 80 anos, está novo, parece que tem 70 [anos]. Quero cumprimentar o nosso querido companheiro Eduardo Paes, prefeito da cidade do Rio de Janeiro. (LULA, 2010, p. 1)

(...) Well, my dear comrades of Rio de Janeiro, my dear comrades of the Complexo do Alemão, my dear comrade Sérgio Cabral, governor of Rio de Janeiro, and his dear partner Adriana Ancelmo Cabral, my dear comrade Marisa, my comrade minister Marcio Fortes, from the Ministry of Cities; Dulci, from the General-Secretary of the Presidency; Franklin Martins, from the Ministry of Social Communication, our comrade Eloi Ferreira de Araujo, minister of Racial Equality, I would like to greet our dear comrade Luiz Fernando Pezão, vice-governor and the right and left arm of comrade Sergio Cabral, I would like to greet the federal congresswoman Cida Diogo; congressman Jorge Bittar. Happy Birthday, Jorge Bittar. You, for someone who is 80 years old, looks like someone who is 70 (years). I would like to greet our dear comrade Eduardo Paes, mayor of the city of Rio de Janeiro. (LULA, 2010, p. 1) 
Note that Lula repeated the noun 'companheiro' [comrade] throughout this stretch of discourse. The term is associated with a discursive memory of the Brazilian political left. It indexes a relationship between peers who work together and share a collective struggle for better life conditions for the working class. After the media exposure and political influence of Lula in the workers' strikes in the 1970s, in addition to the creation of the PT in 1980, the term 'companheiro' became a trademark of Lula himself. Now it is also the mark of a party and a generation of politicians and left-wing activists who fought for the democratization of the country after 20 long years of military dictatorship (1964-1985).

Lula also often combined the noun 'comrade' with the adjective 'dear.' This usage seems to imply that his interlocutors were not only his political allies, but also those who were part of a space of proximity, partnership, and friendship. In short: People the president trusted.

In 2010, Lula enjoyed great popularity. At the time, his presidential term of almost 8 years had coincided with intense economic growth. Most of the political authorities addressed by Lula were part of the political multiparty alliance of the PT in the federal government. At the local level, the city administration and the government of Rio de Janeiro had both received an enormous amount of finance resources from the federal government in order to implement programs like the Program of Acceleration of Growth (PAC) and Minha Casa, Minha Vida. Sergio Cabral was the candidate for re-election as governor of Rio. Since the beginning of his speech, Lula made clear that "everyone was together for Rio," an echo of the slogan of Mr. Cabral's campaign.

It is fundamental to invoke this political background in order to understand Lula's moves within the system of restrictions that constrain a President's discourse. Lula constantly addressed the governor, evoking the former's accomplishments and resemblance with the people of Rio de Janeiro. In the following stretch of discourse, Lula addressed Sergio Cabral while expressing gratitude to God's blessings:

(...) quero primeiro, Sérgio, agradecer a Deus, porque acho que todo dia, todo dia nós temos que levantar, colocar nossas mãos para o céu e agradecer por mais um dia. Muitas vezes, a gente se esquece de agradecer, muitas vezes, a gente se levanta nervoso com coisas menores, e a gente se esquece que o dom maior é a nossa vida e, por 
ela, nós temos que agradecer todo dia ao nosso Criador. (LULA, 2010, p. 2)

I would like to first of all, Sergio, thank God, because I think that every day, every day we have to wake up, raise our hands up to the sky and thank for one more day. Many times we forget to thank, many times we wake up in a nervous mood, we forget that the greatest blessing is our life and, for it, we have to thank our Creator every day. (LULA, 2010, p. 2)

He then added that:

(...) A história do Rio de Janeiro será dividida em dois momentos, antes do Sergio Cabral e depois do Sergio Cabral, porque o Sergio Cabral, ele traz dentro da alma dele aquilo que é a alma do carioca. Ele não um intelectual carioca, ele é o carioca. Ele não é um sambista carioca, ele é o carioca. Em qualquer coisa que você tentar procurar o símbolo de um carioca, está na cara, no jeito e na espontaneidade do companheiro Sergio Cabral. (LULA, 2010, p. 2)

(...) The history of Rio de Janeiro will be divided up in two moments, before Sergio Cabral and after Sergio Cabral, because Sergio Cabral, he brings inside his soul that which is the Carioca soul. He is not a Carioca intellectual; he is the Carioca. He is not a Carioca samba singer; he is the Carioca. Wherever you look for the symbol of a Carioca, it is in the face, in the manners and in the spontaneity of comrade Sergio Cabral. (LULA, 2010, p. 2)

In addressing Sergio Cabral as one of his privileged interlocutors, Lula first iterated religious signs. Scholars in the anthropology of secularism correlate the construction of modernity with the denial of pre-modern practices and sensibilities such as religiosity (ASAD, 2003; MAHMOOD, 2009). Lula subverted this modern construction of politics and subjectivity by bringing religious sensibilities into the political realm. ${ }^{2}$ In other words,

\footnotetext{
${ }^{2}$ In entangling religion and politics, Lula is also strategically drawing on the sensibilities of Brazil's immense Christian (especially Catholic) population.
} 
he spoke as someone from the people, uttering a language as religious as the people's language (SEGATO, 1995) while simultaneously ressignifying this non-modern grammar as the proper language of Brazilian politics.

Next, Lula used the term 'Carioca' to reference Sergio Cabral. Carioca is both a noun and an adjective that refers to the native inhabitants of Rio de Janeiro. His invocation of a Carioca body and soul was intertwined with his government's efforts to upgrade Rio's symbolic and economic status. After a long period of political and economic decay following the transference of the federal government from Rio to Brasília in 1960, Rio de Janeiro became, in the second term of Lula's presidency (2006-2010), the epitome of Brazil's contemporary economic growth and change.

In his address to governor Cabral, Lula at once displayed his awareness of the ritualistic language of politics and destabilized the "normality" of this language by bringing in the non-modernity of religion and a feeling of belonging related to the "authentic" context of the Carioca. His style also framed authorities occupying high positions in the vertical and unequal organization of Brazilian society as friends who were willing to come down to the place where the People belong. On stage, his dear comrades were framed as neither traditional Carioca intellectuals (Lula's predecessor and political opponent, Fernando Henrique Cardoso, was an intellectual from Rio de Janeiro who made an academic and political career in São Paulo) nor famous samba singers, but as spontaneous and "average" Cariocas.

\section{Metaphor and Populism}

To highlight the importance of Rio de Janeiro's politicians, Lula explored yet another feature of language and discourse: metaphor. For instance, he argued that, with the new political administration, Rio witnessed a "miracle of the multiplication of loaves" (LULA, 2010, p. 3). He then criticized Cabral and mayor Eduardo Paes' predecessors (Rosinha Garotinho and César Maia, respectively) by stating that:

(...) esse milagre da multiplicação dos pães aqui no Rio de Janeiro se deve à capacidade de interlocução que tem o Sérgio Cabral que tem o companheiro Pezão, e que tem o Eduardo Paes na prefeitura, que é outro alívio que vocês deram a vocês mesmos. É como se vocês vivessem com 
dor de cabeça a vida inteira, uma dor de cabeça crônica (com) um prefeito que parecia um pavão... vocês elegeram Eduardo Paes... é como se vocês tivessem tomado um remédio para acabar com a dor de cabeça de quem agia apenas pensando em si próprio. (LULA, 2010, p. 3)

(...) such miracle of the multiplication of loaves here in Rio de Janeiro stems from the ability of interlocution that Sergio Cabral has, as well as the likened ability that both comrades Pezão and Eduardo Paes have, which is yet another relief that you guys gave to yourselves. It is like you guys had a headache that lasted forever, a chronic headache with a mayor who behaved like a peacock... then you elected Eduardo Paes... it is like you had taken a medicine to end a headache caused by someone who acted only on behalf of himself. (LULA, 2010, p. 3)

Lula addressed both his interlocutors and opponents by means of metaphors. On the one hand, he mocked previous local politicians by dismissing them as pretentious leaders who ended up giving long-lasting headaches to the people. He referred to Rio de Janeiro's former mayor, Cesar Maia, as a "peacock," and to the period before Cabral and Paes" administrations as "a chronic headache." On the other hand, he associated his political allies and consequently himself with the Carioca lifestyle. In Lula's speech, Cabral was the very Carioca soul.

As Lula's speech was being uttered in a group of favelas, the claim of being an authentic Carioca may have two possible effects. First, Lula played with regional identities: He is from the poorest geographic region of Brazil, the Nordeste. Residents from the Nordeste occupy the place of pre-moderns in the Nation's imaginary (SILVA, 2012), a symbolic location also occupied by people from peripheral neighborhoods like the Alemão. In other words, his being from a region traditionally associated with hunger and misery in popular discourse authorized him to assign trust to his ally Cabral, the very icon of the Carioca soul, as being able to do the best for those who share Lula's previous marginalized condition. Lula's politics here were both national and local. Second, to be a Carioca also stood out as a differential marker from Rio de Janeiro's "old politics." Both Anthony Garotinho and Rosinha Garotinho are from the municipality of Campos, in the North of Rio de Janeiro State. They 
effectively become foreigners when it comes to the Carioca demands of the capital city.

Lula also drew on such metaphorical notions as proximity and religiosity to perform the locus of enunciation of a politician who is close to his allies and to God, while being wary of the dangers of distance and flamboyance.

Ricoeur (1977) argues that metaphor produces meaning by combining signs that are already part of the structure of experience and understanding of the social world. Lula utters metaphors that combine politics with the everyday life of ordinary people, thereby making his speech more "concrete." Lula breached the modern ideology of secular politics by conflating his political deeds with religious symbols, for instance by invoking the image of God to feed the hope that things will get better. He "[thanked] God" for one more day and referred to Rio's politicians as those who made the "miracle of the multiplication of loaves" (LULA, 2010, p. 2-3).

Lula also couched his populism in metaphorical notions such as (relief from) pain and suffering. The moments in his speech in which these notions are encoded are all the more relevant as they reveal the resignification of the pain and suffering that historically marked the Brazilian poor and especially the Nordestinos like him. The promise of a messianic time - proper of religious notions enacted in his discourse is anticipated from the after-life of paradise into the present time of the Brazilian welfare State. The following excerpt is indicative of this operation:

(...) Os filhos de vocês, agora, podem estudar em uma escola com ar-condicionado dentro da escola, o que não poderia continuar a ser privilégio dos setores mais abastados. Afinal de contas, não pode o filho de um estar em uma escola com ar-condicionado, e o filho de outro não conseguindo nem escrever, porque o suor molhava a folha do caderno em que ele tinha que escrever. (LULA, 2010, p. 4)

(...) Your children now can study at a school with airconditioning. This should no longer be the privilege of the rich. To begin with, it's a contradiction that someone's child studies in a school with air-conditioning while another's child cannot even write because the room is so hot that the sweat drips down into the notebook. (LULA, 2010, p. 4) 
Lula thus positioned the accomplishment of the policies devised in his administration as the relief for the corporeal suffering of the people. Natural factors such as heat are no longer impediments for the people's realization of their citizenship. In drawing from the same corporeal field in which our necessity as humans is grounded, Lula claims to have transformed a state of necessity into a state of rights. As much as at a local scale the children and the families in the Complexo do Alemão would have their suffering and pain alleviated by social programs, his political alliances would amount, at the broader scale of Rio's politics, to the remedy for an abiding "headache" afflicting Fluminense people. The messianic "país do futuro" (country of the future) is pragmatically rendered into the country of the now.

Lula's metaphoric language is yet another source of the polyphony of his discourse. It places the "abstract" language of politics in the "concrete" ground of proximity, religion, and everyday corporeal life. Yet, while such metaphors do approximate the President and the poor, they also reveal an uncanny conception of Brazilian political language. Before Lula, all previous presidents had diplomas of higher education and were recognized as "doctors." The term "doctor" in Brazil refers primarily to a physician, but is also used as a prestigious title often conferred to a small part of the Brazilian population - a white male from the economic elite. It also refers to someone holding a doctoral degree, although the latter reference is much less widespread. In exploring a metaphoric language that entextualizes signifiers proper to the People, Lula enacted a linguistic identity that broke with previous utterances of Brazilian politics - utterances that would make a sharp distinction between the "head of state" and his people.

\section{Lula's Populism}

Lula also made jokes and told a few stories of the families benefiting from public policies:

(...) Pois bem, companheiros e companheiras, a entrega destas unidades habitacionais significa um novo começo para cada uma das famílias aqui beneficiadas. Por meio do programa "Minha Casa, Minha Vida" (...), companheiras como Alexandra de Jesus e Ana Paula Silva estão vendo seus sonhos, que pareciam impossíveis, se tornarem realidade. (LULA, 2010, p. 4) 
(...) Thus, my comrades, the inauguration of these houses amounts to a new beginning for every family here. By means of the Program "My Home, my Life" (...), comrades such as Alexandra Jesus and Ana Paula Silva can now see that their dreams, impossible to be realized before, are coming true today. (LULA, 2010, p. 4)

Lula thus produces his proximity to the people by means of discursive properties such as metaphor and polyphony. In this section, we want to draw on Laclau's (2007) logic of populism to discuss how Lula entangles his locus of enunciation with populism.

In Brazil and elsewhere, classic theories of populism tend to frame this political form negatively. Weffort and Ianni are two academic icons of such position in Brazil. Weffort (1989) claims that populism in Brazil, after its emergence in the 1930s, manifested itself in two forms: as a style of government and as mass politics. The author couches his explanation of the success of populism in Brazil in three elements: repression, manipulation, and satisfaction. The entanglement between State repression, the manipulation of the masses and the satisfaction of workers who saw some of their demands being accommodated would give rise to a "populist pact" in Brazil.

In his analysis of the political history of Brazil and the reasons behind the 1964 civil-military coup d'état, Ianni published, in 1968, O colapso do populismo no Brasil, or The Collapse of Populism in Brazil (IANNI, 1989). He circumscribes populism to the years of 1945 and 1964 - a period he termed "populist democracy". Ianni sees the 1964 coup as the disintegration of populism in Brazil, i.e., the collapse of an economic development model characteristic of a transition period (from an agriculture society into an urban and industrial one) conducted by an interventionist State and by charismatic leaders who sought to legitimize themselves in mass politics.

According to Ferreira (2001), both Weffort and Ianni regard populism as a "deviation" from the natural course of political life. The "deviation" theory is grounded on a teleologic view of Marxism, namely that the working classes, in becoming aware of their class positionality, would find their own vocation - the socialist revolution. Grounded on repression, manipulation, and cooptation, (this rendition of) populist politics, however, would have prevented workers from an autonomous initiative. In this perspective, workers and other popular segments are 
less authors than witnesses of the political process. They would thus be patients rather than agents of history.

Laclau's positions departs from the classic view. He devises a discursive theory of populism, arguing that the latter ought to be understood not as a political system but as a symbolic game of negotiation between different social actors. Populism is not a strategy of manipulation from above, but a bilateral political game. Populism is less a movement (identified with a certain ideological orientation) than a logic of political struggle, one that operates on distinct ideological grounds and orientations.

In diverging from classical theories, Laclau regards populism as the proper of the political arena. Society is divided into two camps, and populism takes place when those from "below" interpelate power. This typically comes during moments of crisis of hegemony, when social demands do not find satisfactory answers in the institutional system. In Laclau's own words,

Populism is not an irrational set of practices that somehow undermines more rational coherent forms of political conduct. Rather, all politics contains a populist dimension (...). [I]t starts at a time of crisis, when the ideology of the people is articulated in a popular democratic antagonism against the ideology of dominant bloc. (LACLAU, 2005, p. 47)

Populist logic calls into question a certain normal political universe. Lula permeates his speech with such popular and everyday imagery that he does away with the "objectivity" of the political, as well as with the supposed autonomy of politics in relation to other spheres of social life, such as religion or soccer. In Lula's speech, politics is built up by vague and indeterminate meanings. However, as Laclau (2005) claims, vagueness and indeterminacy are not a "problem" for populist logic. Rather, this hybrid rhetoric, by mixing different spheres of social life, makes clear that social and political reality is itself vague and indeterminate. Thus, rather than interpreting such language as deviation, we ought to understand it as a break with certain expectations about what should be the language of politics - a language traditionally infused with ascetic and Eurocentric values. 
Lula's locus of enunciation becomes all the more populist if we consider that he was elected President during a crisis of the hegemony of the traditional ruling class in Brazil. During the years of redemocratization (1990-2002), Brazil had been ruled by parties that applied principles of radical modern liberal ideology to the economy and to the State. During the international crises of markets in the late 1990s, the Brazilian economy suffered a significant negative impact resulting from the economic policies adopted by then-President Cardoso in his second term (1999-2002).

The population felt the political and economic crisis and longed for change. A specific voice of the "people" began to be heard: A voice demanding more jobs, access to education, health, public transportation, security etc. In short, Lula clearly articulated a set of historical demands from Brazil's lower middle classes.

When he was first elected in 2002, Lula would then become the symbol of change. In Laclau's (2005) terms, Lula's image was that of an "empty signifier." The concept is closely related to the way Laclau defines populist logic. Strictly speaking, an empty signifier is a signifier without a signified. This occurs when a discourse universalizes its content in such way that it becomes impossible to construct an accurate meaning. An empty signifier is a discourse that expands its contents, becoming inflated by its meanings. Laclau relates this double movement of emptying and overflowing of the signifier to the political sphere, arguing that these empty signifiers condense at a given time in history around a series of particular demands of individuals and groups that were not institutionally answered. When a series of social demands cannot be absorbed differentially by institutional channels, they become unsatisfied demands that enter into a relationship of equivalence with one another and thus crystallize around common symbols. Some leaders exploit these symbols by interpellating the frustrated masses and incarnating a process of popular identification that ends up producing "the people" as a collective actor to confront the existing regime with the purpose of demanding change.

Lula became the symbol for the resolution of varied and distinct demands, including housing, health, education, and food. These demands were condensed and became equivalent, with Lula as the icon of the unraveling of all of these long-lasting problems. It was no coincidence that the symbol of his first campaign had the following motto, "Hope 
overcame fear." In many respects, Lula was then the embodiment of hope and happiness.

This position was further strengthened with the establishment of the imaginary of an opposition between the people and the rulers that were in power before Lula - representatives of the agricultural, industrial and military political elites. In the recent history of Brazilian democracy, Lula was the first person from the poor Nordeste to be elected president, and the first with little formal education. In Signorini's terms (2014, p. 178), Lula disrupted previous standards of presidential discourse and literacy, in that he blurred traditional correlations between "discursive genre and sociopragmatic function in the public sphere (informal conversation instead of formal speech; performative action instead of erudite oratory)"; and also made vague associations between "linguistic standards and the legitimacy of political authority," thus challenging "boundaries normally taken as stable and well-defined by traditional sociopolitical and sociolinguistic orders".

Lula was also the first candidate to be elected from the PT, the first party in Brazil that was not created by the elites. To many, Lula embodied the possibility of change and redemption for the "forgotten people."

Laclau claims that in populism the "people" are not a "datum" of the social structure, but rather a discursive construction. The "people" are less than the whole body of citizens - the populus. In populism, the people are equivalent with the "plebs", the underprivileged, inasmuch as the people claim to be "the only legitimate populus - that is, a partiality which wants to function as the totality of the community" (LACLAU, 2005 , p. 81). The populist production of the "people" requires an operation that presents the plebs as the entire populus.

This construction is established by means of an antagonism between sectors of the society: the "people" versus the "elite". The populist logic strategically promotes a social division by using privileged signifiers that condense the whole field of actors into two antagonistic sides (for the enemy, the "regime", the "oligarchy", the "dominant groups" etc., and for the oppressed, the "people", the "nation", the "silent majority," and so on).

Discourses about Lula often display such imaginary opposition between the two sides of the dispute. Silva (2012) discusses one such opposition by conducting a textual analysis of the ways in which Veja (a weekly magazine widely read in Brazil, also known for its right-wing 
bias) delegitimizes Lula's electors as non-modern subjects. One of Silva's examples is a Veja magazine article profiling Lula voters. On August 16, 2006, when Lula was running for his reelection, Veja displayed a young woman from the Nordeste, Gilmara Cerqueira, smiling on the cover while holding her voter identification card. The main caption was: "She can decide the election." Just below the captions, the subtitle read: "Nordestina, 27 years, average education, 450 Reais per month (\$115 per month), Gilmara Cerqueira portrays the voter that will tip the scales in October."

Both in the cover and in the main article, Veja exhibited linguistic and visual elements that portrayed the modern field of politics in Brazil, iconized by elements such as the electoral card held by Gilmara and expressions like "Brazilians who work and pay taxes," which referenced supporters of the right-wing opposition candidate, Geraldo Alckmin. Veja consciously represented an imagined community of readers, the nation's "good" citizens.

In our analysis of Lula's locus of enunciation, we argue that the sign "people" comprises precisely those left out of this "imagined community" produced by this right-wing magazine. Below are some portions of Lula's speech in which the word "people" was uttered:

(...) Portanto, Sérgio, (...) você está dizendo que é possível fazer as coisas ficarem melhores quando a gente gosta do povo, quando a gente respeita o povo e quando a gente não faz distinção nem pela cor, nem pela idade, nem pela religião e muito menos pelo status social. (LULA, 2010, p. 4)

(...) Therefore Sergio (...) you are saying that you can make things better when we like the people, when we respect the people and when we do not distinguish people by color, or by age, nor by religion and much less by social status. (Lula, 2010, p. 4)

(...) verdade que tem traficantes aqui e tem bandidos aqui (...) Mas nós temos que provar, todo santo dia, que a maioria do povo daqui é povo que vive do seu salário, do seu suor e do seu sangue. (LULA, 2010, p. 7) 
(...) it is true that here we have drug dealers, thugs (...) But we have to prove every single day that the majority of the people here are people who earn a salary, and who live out of their sweat and blood. (LULA, 2010, p. 7)

Note that Lula had as his audience not only fellow politicians, but a majority of residents who shared a similar socioeconomic condition with Gilmara Cerqueira - people who were unemployed or working in the informal sector, with low levels of schooling, and with per capita income between zero and two minimum wages (or between zero and 400 US Dollars). They also belonged to the group familiar with most of Lula's metaphors: religious people who enjoyed everyday, humble activities.

In the passages above, 'people' is synonymous with 'workers', but not just any workers. Lula's people are those who have to prove every day that they are not drug dealers. By the end of his speech, Lula stated: "Rio de Janeiro is not a state of bandits, neither of drug dealers" (p.7). He adds that, "we have to prove every day, every sacred day, that the majority of the people here live out of their sweat and blood" (p.7). Both utterances contradict historical constructions in the corporate media that, for at least two decades (1990s and 2000s), treated the Complexo do Alemão as a space of disease, violence, and decadence. Lula expanded the signifier "the people" in such a way that they became the bearers of the promises of the Welfare State. Housing, health, education, and security are now keywords of a Welfare State language that Lula's government helped to develop (SINGER, 2012).

While recognizing the overall scenery of social and economic hardship among the people living in the Complexo do Alemão, Lula in his speech also affirmed that his political commitment would improve their lives. Lula reframed the space and time of the people he was talking to: while they live in areas considered by mainstream discourses as only fit for drug trafficking and crime, Lula positioned them as individuals who deserve to be respected regardless of color, age, religion or social status. Lula at once praised and produced the "people," the plebs, the underprivileged. 'The people' is an empty signifier that Lula explored as if to delimit it against 'the elites', or those who have always been in power in Brazilian society; those who, in Lula's own terms, are "the more affluent sectors of society," or in Veja's words, "the Brazilians who work and pay taxes." 


\section{Conclusions}

The generic features of Lula's speech - the acknowledgement of political and institutional authorities and the recontextualization of narratives of displaced families who would benefit from Minha Casa, Minha Vida - were entangled with the process of producing a ritual and following protocol procedures that constrain the speech of heads of state in particular contexts. This example of Lula's speech supports the argument that the subject who speaks in ritual contexts is framed by an order that disciplines, controls and defines the (good) forms of life. On the one hand, Lula stood as an interlocutor of the Welfare State, positioning himself as a leader that could ensure State support in providing minimal socioeconomic guarantees to the people (plebs): income, health, education and housing. Lula thus followed institutional rules.

On the other hand, with a unique style that marks his identity as a "simple man," Lula recontextualized real life stories and popular signs such as the admiration for the sacred in order to resonate with the poor. In a double bind, Lula fulfilled the institutional role of the State in recognizing and meeting social demands, while subverting certain expectations regarding a "President's locus of enunciation," thus occupying the uncanny place of someone in an elite position speaking the language of the plebs. This image is foreign to the tradition of political discourse in Brazil and therefore marks Lula's singularity as president.

Lula's discourse is therefore constituted by an anti-institutional dimension and by a challenge to political normalization, or the usual order of things. In wittingly exploring some unorthodox features of language and discourse, Lula produced his locus of enunciation as a voice from the people, as if the people were talking to the people.

\section{Acknowledgements}

This article was partially funded by a grant from the Fundação de Amparo à Pesquisa do Estado do Rio de Janeiro - FAPERJ (Process: 100.101/2012). 


\section{References}

ASAD, T. Formations of the secular: Christianity, Islam, Modernity. Stanford: Stanford University Press, 2003.

ARENDT, H. The Human Condition. Chicago: Chicago University Press, 1958.

AUSTIN, J . How to do things with words. Oxford: Oxford University Press, 1962.

BAKHTIN, M. Speech Genres and Other Late Essays. Austin: University of Texas Press, 1986.

BAKHTIN, M. Problems of Dostoevsky's Poetics. Minneapolis: University of Minnesota Press, 1993.

BAUMAN, R.; BRIGGS, C. Poetics and performance as critical perspectives on language and social life. Annual Review of Anthropology, v.19, p.59-88, 1990.

BENVENISTE, É. Problems in General Linguistics. Miami: University of Miami Press, 1973.

BLOMMAERT, J. Discourse: A critical introduction. London: Routledge, 2005. https://doi.org/10.1017/CBO9780511610295.

BLOMMAERT, J. Language Ideology. In: BROWN, K. (Ed.). Encyclopedia of Language \& Linguistics. 2.ed. Oxford: Elsevier, 2006. v. 6, p.510-522.

BLOMMAERT, J. Grassroots literacies. Writing, identity in Central Africa. London: Routledge, 2007.

BOURDIEU, P. Outline of a theory of practice. Cambridge: Cambridge University Press, 1977.

BRIGGS, C. The Gallup poll, democracy, and the vox populi: Ideologies of interviewing and the communicability of modern life. Text \& Talk, v.5, n.6, p.681-704, 2007.

DALTOÉ, A. Divulgação do discurso político: as metáforas de Lula e suas formas de interdição. Linguagem em (Dis)curso, v.11, n.3, p.585606, 2011. 
FAIRCLOUGH, N. Discourse and Social Change. Cambridge: Polity Press, 1993.

FERREIRA, J. O nome e a coisa: o populismo na política brasileira. In: . O populismo e sua história: debate e crítica. Rio de Janeiro:

Civilização Brasileira, 2001. p. 60-124.

FOUCAULT, M. The Archaelogy of Knowledge. London: Tavistock, 1972.

FOUCAULT, M. The Order of Discourse. In: YOUNG, R. (Ed.). Untying the Text: A Post-Structuralist Reader. Boston: Routlege \& Keagan Paul, 1981. p.51-78.

GARCEZ, P.; SCHULZ, L. Olhares circunstanciados: etnografia da linguagem e pesquisa em Linguística Aplicada no Brasil. D.E.L.T.A., v. 31, n. 3, p. 1-34, 2015.

IANNI, O. A formação do Estado populista na América Latina. São Paulo: Ática, 1989.

IANNI, O. O colapso do populismo no Brasil. Rio de Janeiro: Civilização Brasileira, 1994.

IBGE. Censo 2010. Disponível em: <http://censo2010.ibge.gov.br>. Acesso em: 10 mar. 2015.

LACLAU, E. On Populist Reason. London: Verso, 2005.

LULA, L. The President's speech delivered in October 25, 2010, at the inauguration ceremony of units from Minha Casa, Minha Vida designed for families displaced by the mudslides of April 2010, Disponível em: $<$ http://www.biblioteca.presidencia.gov.br/ex-presidentes/luiz-inaciolula-da-silva/discursos/2o-mandato/2010/2o-semestre/25-10-2010discurso-do-presidente-da-republica-luiz-inacio-lula-da-silva-nacerimonia-de-entrega-de-unidades-do-programa-minha-casa-minhavida-para-familias-atingidas-pelas/view>. Acesso em: 15 mar. 2015.

MAHMOOD, S. Religious reason and secular affect: an incommensurable divide? In: ASAD, T.; BROWN, W.; BUTLER, J.; MAHMOOD, S. Is Critique Secular? Blasphemy, injury, and free speech. Berkeley: University of California Press, 2009. p. 64-100. 
MENDONÇA, D.; LOPES, C. A. Apresentação: O populismo na visão inovadora de Laclau. In: LACLAU, E. A razão populista. São Paulo: Três Estrelas, 2013. p. 9-17.

MIGNOLO, W. Editor's Introduction: Loci of Enunciation and Imaginary Constructions: The Case of (Latin) America. Poetics Today, v.15, n.4, p.505-521, 1994.

OLIVEIRA, B. Políticas públicas e participação popular na implementação do PAC Social no Complexo do Alemão, RJ. 2010. Dissertação (Mestrado em Política Social) - Universidade Federal Fluminense, Rio de Janeiro, 2010.

NOBRE, M. Imobilismo em movimento: da abertura democrática ao Governo Dilma. São Paulo: Cia. das Letras, 2013

PINTO, J. Trajectories of the Black Female Body in Brazil. Circulations of Racist and Antiracist Representations on a TV Show. Pragmatics and Society, v. 6, n. 2, p.197-216, 2015.

RICOEUR, P. The rule of metaphor. Toronto: University of Toronto Press, 1977.

SEGATO, R. Santos e daimones: o politeísmo afro-brasileiro e a tradição arquetipal. Brasília: Editora UnB, 1995.

SILVA, D. Pragmática da Violência: O Nordeste na Mídia Brasileira. Rio de Janeiro: 7 Letras, 2012.

SINGER, A. Os sentidos do Lulismo: Reforma Gradual e Pacto Conservador. São Paulo: Cia. das Letras, 2012.

SIGNORINI, I. Por uma teoria da desregulamentação linguística. In: BAGNO, M. (Org.). A linguística da norma. São Paulo: Edições Loyola, 2002. p.93-123.

SIGNORINI, I. Língua oficial (oficial pra quem?). In: CORREA, M.; BOCH, F. (Org.). Ensino de língua: representação e letramento. Campinas: Mercado de Letras, 2006. p.123-138.

SIGNORINI, I. A Brazilian ex-President's Public Speech: A Threat to the Existing Order? In: GORRTZEL, T.; ALMEIDA. P. R. (Ed.). The Drama of Brazilian Politics. From Dom João to Marina Silva. New York: Kindle Book, 2014. p.176-194. 
STREET, B. Ethnography of writing and reading. In: OLSON, D. R.; TORRANCE, N. (Ed.). The Cambridge handbook of literacy. Cambridge: Cambridge University Press, 2009. p. 332-328.

van DIJK, T. Discourse and Power. London: Palgrave Macmillan, 2008. VENTURA, Z. Cidade Partida. São Paulo: Cia. das Letras, 1995.

WEFFORT, F. O populismo na política brasileira. Rio de Janeiro: Paz e Terra, 1989.

WODAK, R. The Discourse of Politics in Action: Politics as Usual. New York: Palgrave Macmillan, 2011.

ZALUAR, A. Youth, drug traffic and hyper-masculinity in Rio de Janeiro. Vibrant, v.7, n. 2, p. 7-27, 2010. 